\title{
Commentary: Underestimating the Challenges of Avoiding a Ghastly Future
}

\author{
Jevgeniy Bluwstein ${ }^{1 *}$, Adeniyi P. Asiyanbi ${ }^{2}$, Anwesha Dutta $^{3}$, Amber Huff $^{4}$, \\ Jens Friis Lund ${ }^{5}$, Salvatore Paolo De Rosa ${ }^{6}$ and Julia Steinberger ${ }^{7,8}$ \\ ${ }^{1}$ Department of Geosciences, University of Fribourg, Fribourg, Switzerland, , 2 Department of Geography, University of Calgary, \\ Calgary, AB, Canada, ${ }^{3}$ Chr. Michelsen Institute, Bergen, Norway, ${ }^{4}$ Institute of Development Studies, University of Sussex, \\ Brighton, United Kingdom, ${ }^{5}$ Department of Food and Resource Economics, University of Copenhagen, Copenhagen, \\ Denmark, ${ }^{6}$ Lund University Centre for Sustainability Studies, Lund University, Lund, Sweden, ${ }^{7}$ Institute of Geography \& \\ Sustainability, University of Lausanne, Lausanne, Switzerland, ${ }^{8}$ Sustainability Research Institute, University of Leeds, Leeds, \\ United Kingdom
}

Keywords: sustainability, malthusianism, population growth, social science, crisis, biodiversity, climate change

\section{A Commentary on}

\section{OPEN ACCESS}

Edited by:

Christoph F. J. Meyer,

University of Salford, United Kingdom

Reviewed by:

Esther Turnhout,

Wageningen University and

Research, Netherlands

Stephen Thomas Garnett,

Charles Darwin University, Australia

${ }^{*}$ Correspondence:

Jevgeniy Bluwstein

jevgeniy.bluwstein@unifr.ch

Specialty section

This article was submitted to

Global Biodiversity Threats,

a section of the journa

Frontiers in Conservation Science

Received: 11 February 2021

Accepted: 19 April 2021

Published: 13 May 2021

Citation:

Bluwstein J, Asiyanbi AP, Dutta A, Huff A, Lund JF, De Rosa SP and Steinberger J (2021) Commentary: Underestimating the Challenges of

Avoiding a Ghastly Future.

Front. Conserv. Sci. 2:666910.

doi: 10.3389/fcosc.2021.666910
Underestimating the Challenges of Avoiding a Ghastly Future

by Bradshaw, C. J. A., Ehrlich, P. R., Beattie, A., Ceballos, G., Crist, E., Diamond, J., et al. (2021). Front. Conserv. Sci. 1:615419. doi: 10.3389/fcosc.2020.615419

\section{INTRODUCTION}

Bradshaw et al. (2021) make a call to action in light of three major crises-biodiversity loss, the sixth mass extinction, and climate disruption. We have no contention with Bradshaw et al.'s diagnosis of the severity of the crises. Yet, their call for scientists to "tell it like it is," their appeal to political "leaders," and the great attention they afford to human population growth as a main driver underpinning the three crises, rest on contested assumptions about the role of science in societal transformations, and are scientifically flawed and politically problematic. In this commentary, we challenge Bradshaw et al.'s assumptions concerning the nature of science, polity, and humanity as well as the implicit politics underlying their analysis and messaging. We end with an alternative call to action.

\section{THERE IS ONE SCIENCE}

Bradshaw et al. assume the existence of a united scientific community that can and should "tell it like it is" (p. 6). While there is broad scientific consensus on the existence and anthropogenic drivers of the crises, there is far less agreement on how we should understand the defining features of the Anthropocene, let alone how to address the crises (Biermann and Kim, 2020). The sciences of biodiversity conservation, global environmental change and sustainability are plural fields of multiple-at times competing and contested-knowledges, goals, and values (Evans, 2021; Lahsen and Turnhout, 2021). For instance, Bradshaw et al. highlight the role of human population growth as a central driver of the three crises. Contrary to this, historians and social scientists emphasize the role of centuries of European colonization and fossil capitalism (Malm and Hornborg, 2014; Moore, 2016). 


\section{THERE IS ONE POLITY}

Bradshaw et al. assume that political leaders can be motivated to respond to the three crises through more "foreboding" warnings by scientists and a "good communications strategy" to raise an allegedly "weak" awareness. This logic flies in the face of long-established evidence within the social sciences. First, science-based awareness (or lack thereof) of environmental processes and crises is not the driving force in policy and politics (Jerneck et al., 2011; Fesenfeld and Rinscheid, 2021; Lahsen and Turnhout, 2021). Political and societal changes are driven by a complex set of societal conflicts, usually underpinned by social movements who contest the status quo by acting on real or perceived political, social, economic, and environmental inequalities and injustices (Giugni et al., 1999; Sinha, 2016). Scientists often play a role in such political struggles, but these struggles cannot be reduced to science-led processes of positive change (Castree, 2019; Isgren et al., 2019). Rather, science can and continues to be harnessed to achieve different and even competing political goals and environmental outcomes (Mansfield, 2021). Second, millions of people are already acutely aware of the socio-ecological crises described by Bradshaw et al. (2021) because they face them every day. In fact, many of them are actively trying to stop the assault on the environments that they depend on for their livelihoods (Scheidel et al., 2018, 2020), often risking their property, health and even their lives (Le Billon and Lujala, 2020). The idea that only the "future" will be "ghastly" reinforces a western, white and elitist framing of reality, since the present is already experienced as apocalyptic by many frontline communities (Silver, 2018; Whyte, 2020).

\section{THERE IS ONE HUMANITY}

Bradshaw et al. use well-worn neo-Malthusian tropes to frame an undifferentiated "humanity" in general, and human population growth more concretely, as a key driver of "many societal problems," from food insecurity and malnutrition, soil degradation and biodiversity loss, pandemics and resource scarcity, crowding and joblessness, deteriorating infrastructure and bad governance, and conflicts and wars. Scientifically, a massive body of scholarship has thoroughly questioned such neo-Malthusian anxieties (Harvey, 1974; Leach and Fairhead, 2000; Peluso and Watts, 2001; Fletcher et al., 2014; Hendrixson and Hartmann, 2019; Kallis, 2019; Mehta et al., 2019; Ojeda et al., 2019). Politically, neo-Malthusian tropes offer an ethically problematic and dangerous framing that can mobilize forces on the far right (Gilman, 2020), while displacing much needed attention from growing patterns of uneven development, resource use, affluent consumption, poverty and inequality (Harvey, 1974; Wiedmann et al., 2020; Brand and Wissen, 2021).

\section{REFERENCES}

Biermann, F., and Kim, R. E. (2020). The boundaries of the planetary boundary framework: a critical appraisal of approaches to define a "safe
Less than $10 \%$ of global carbon emissions are attributable to the consumption patterns of the world's poorest half while the top $1 \%$ are responsible for $15 \%$ of total emissions (Oxfam, 2020). Similar patterns of inequality can be observed with energy use (Oswald et al., 2020). At the same time, many globally important biodiversity areas and hotspots are in territories claimed and/or managed by Indigenous peoples, local communities, and Afrodescendants mainly in the global South (Fa et al., 2020) - the very regions whose residents are positioned as environmental threats by Bradshaw et al. (2021). Implicitly then, Bradshaw et al. end up accusing and putting the onus on those who presently lead more sustainable lives (see Greenberg, 2013), who have the least current and historical responsibility for the crises, and who wield the least of a voice in international scientific and political debates about how to address them.

\section{DISCUSSION}

We maintain that there is no universal understanding of the intertwined socio-ecological challenges we face. Nor do established scientific facts speak for themselves. Scientific messaging alone cannot adequately communicate to the public how socio-ecological crises should be addressed. Framing socioecological crises primarily as driven by population growth reveals a western, elitist and neo-colonial bias while it distracts from holding accountable more powerful forces in society.

Importantly, Bradshaw et al. do mention inequality and capitalism in passing as forces standing in the way of needed change. To us, these are not peripheral but central aspects of any scientific analysis that takes seriously the causes and drivers of biodiversity loss, the sixth mass extinction, and climate disruption.

Accordingly, we end our reply with a different call to action. Rather than voicing alarmist warnings, we ask for an engaged scientific community to stand in solidarity with frontline communities affected by and fighting against biodiversity loss and climate emergency all around the world. Rather than distracting attention through neo-Malthusian tropes, scientists should help expose the structural causes and drivers of inequality, overproduction and overconsumption. Rather than legitimizing the status quo by appealing to existing political elites, scientists should actively collaborate with those groups in society that push for and prefigure sustainable ways of living. By doing this, scientists can play their part in charting a course away from our ghastly past and present toward a more socially just and environmentally sustainable future.

\section{AUTHOR CONTRIBUTIONS}

JB wrote the original draft. All co-authors participated in writing, editing, and commenting on the commentary.

operating space" for humanity. Annu. Rev. Environ. Resour. 45, 497-521. doi: 10.1146/annurev-environ-012320-080337

Bradshaw, C. J. A., Ehrlich, P. R., Beattie, A., Ceballos, G., Crist, E., Diamond, J., et al. (2021). Underestimating the challenges of avoiding 
a ghastly future. Front. Conserv. Sci. 1:615419. doi: 10.3389/fcosc.2020. 615419

Brand, U., and Wissen, M. (2021). The Imperial Mode of Living: Everyday Life and the Ecological Crisis of Capitalism. New York, NY; London: Verso.

Castree, N. (2019). An alternative to civil disobedience for concerned scientists. Nat. Ecol. Evol. 3:1499. doi: 10.1038/s41559-019-1023-y

Evans, M. C. (2021). Re-conceptualizing the role(s) of science in biodiversity conservation. Environ. Conserv. 1-10. doi: 10.1017/S0376892921000114

Fa, E. J., Watson, J. E., Leiper, I., Potapov, P., Evans, T. D., Burgess, N. D., et al. (2020). Importance of Indigenous Peoples' lands for the conservation of Intact Forest Landscapes. Front. Ecol. Environ. 18, 135-140. doi: 10.1002/fee.2148

Fesenfeld, L. P., and Rinscheid, A. (2021). Emphasizing urgency of climate change is insufficient to increase policy support. One Earth 4, 411-424. doi: 10.1016/j.oneear.2021.02.010

Fletcher, R., Breitling, J., and Puleo, V. (2014). Barbarian hordes: the overpopulation scapegoat in international development discourse. Third World Q. 35, 1195-1215. doi: 10.1080/01436597.2014.926110

Gilman, N. (2020). The Coming Avocado Politics. What Happens When the EthnoNationalist Right Gets Serious About the Climate Emergency. Oakland, CA: The Breakthrough Institute.

Giugni, M., McAdam, D., and Tilly, C. (eds.). (1999). How Social Movements Matter. Minneapolis, MN; London: University of Minnesota Press.

Greenberg, M. (2013). What on earth is sustainable?: Toward critical sustainability studies. Boom 3, 54-66. doi: 10.1525/boom.2013.3.4.54

Harvey, D. (1974). Population, resources, and the ideology of science. Econ. Geogr. 50, 256-277. doi: 10.2307/142863

Hendrixson, A., and Hartmann, B. (2019). Threats and burdens: challenging scarcity-driven narratives of "overpopulation". Geoforum 101, 250-259. doi: 10.1016/j.geoforum.2018.08.009

Isgren, E., Boda, C. S., Harnesk, D., and O’Byrne, D. (2019). Science has much to offer social movements in the face of planetary emergencies. Nat. Ecol. Evol. 3, 1498-1498. doi: 10.1038/s41559-019-1024-X

Jerneck, A., Olsson, L., Ness, B., Anderberg, S., Baier, M., Clark, E., et al. (2011). Structuring sustainability science. Sustain. Sci. 6, 69-82. doi: $10.1007 /$ s11625-010-0117-x

Kallis, G. (2019). Limits: Why Malthus Was Wrong and Why Environmentalists Should Care. Stanford: Stanford University Press.

Lahsen, M., and Turnhout, E. (2021). How norms, needs, and power in science obstruct transformations towards sustainability. Environ. Res. Lett. 16:025008. doi: 10.1088/1748-9326/abdcf0

Le Billon, P., and Lujala, P. (2020). Environmental and land defenders: global patterns and determinants of repression. Glob. Environ. Change 65:102163. doi: 10.1016/j.gloenvcha.2020.102163

Leach, M., and Fairhead, J. (2000). Challenging neo-Malthusian deforestation analyses in West Africa's dynamic forest landscapes. Popul. Dev. Rev. 26:17. doi: 10.1111/j.1728-4457.2000.00017.x

Malm, A., and Hornborg, A. (2014). The geology of mankind? A critique of the Anthropocene narrative. Anthrop. Rev. 1, 62-69. doi: $10.1177 / 2053019613516291$
Mansfield, B. (2021). Deregulatory science: chemical risk analysis in Trump's EPA. Soc. Stud. Sci. 51, 28-50. doi: 10.1177/0306312720970284

Mehta, L., Huff, A., and Allouche, J. (2019). The new politics and geographies of scarcity. Geoforum 101, 222-230. doi: 10.1016/j.geoforum.2018. 10.027

Moore, J. W. (2016). Capitalism in the Web of Life: Ecology and the Accumulation of Capital. New York, NY; London: Verso.

Ojeda, D., Sasser, J. S., and Lunstrum, E. (2019). Malthus's specter and the anthropocene. Gender Place Culture 27, 316-332. doi: 10.1080/0966369X.2018.1553858

Oswald, Y., Owen, A., and Steinberger, J. K. (2020). Large inequality in international and intranational energy footprints between income groups and across consumption categories. Nat. Energy 5, 231-239. doi: 10.1038/s41560-020-0579-8

Oxfam (2020). Confronting Carbon Inequality. Nairobi: Oxfam.

Peluso, N. L., and Watts, M. (eds.). (2001). Violent Environments. Ithaca, NY; London: Cornell University Press.

Scheidel, A., Del Bene, D., Liu, J., Navas, G., Mingorría, S., Demaria, F., et al. (2020). Environmental conflicts and defenders: a global overview. Global Environ. Change 63:102104. doi: 10.1016/j.gloenvcha.2020. 102104

Scheidel, A., Temper, L., Demaria, F., and Martínez-Alier, J. (2018). Ecological distribution conflicts as forces for sustainability: an overview and conceptual framework. Sustain. Sci. 13, 585-598. doi: 10.1007/s11625-0170519-0

Silver, J. (2018). "Suffocating cities: urban political ecology and climate change as social-ecological violence," in Urban Political Ecology in the Anthropo-obscene: Interruptions and Possibilities, eds H. Ernstson and E. Swyngedouw (London; New York, NY: Routledge), 129-146.

Sinha, M. (2016). The Slave's Cause: A History of Abolition. New Have, CT: Yale University Press.

Whyte, K. (2020). "Indigenous realism and climate change," in Climate Realism: The Aesthetics of Weather and Atmosphere in the Anthropocene, eds L. Badia, M. Cetinić, and J. Diamanti (London: Routledge), 69-81.

Wiedmann, T., Lenzen, M., Keyßer, L. T., and Steinberger, J. K. (2020). Scientists' warning on affluence. Nat. Commun. 11:3107. doi: 10.1038/s41467-020-16941-y

Conflict of Interest: The authors declare that the research was conducted in the absence of any commercial or financial relationships that could be construed as a potential conflict of interest.

Copyright (C) 2021 Bluwstein, Asiyanbi, Dutta, Huff, Lund, De Rosa and Steinberger. This is an open-access article distributed under the terms of the Creative Commons Attribution License (CC BY). The use, distribution or reproduction in other forums is permitted, provided the original author(s) and the copyright owner(s) are credited and that the original publication in this journal is cited, in accordance with accepted academic practice. No use, distribution or reproduction is permitted which does not comply with these terms. 